\title{
Analysing Challenges of Teaching Supply Chain Management in Higher Education Institutions
}

\author{
Nuria Camps
}

Perth College, University of Highlands and Islands, UK

\begin{abstract}
The aim of this paper is to provide an analysis of the main challenges in teaching and learning Supply Chain Management in Higher Education Institutions. It also reviews the perceived challenges faced by university students studying SCM modules as part of business management studies in a Scottish university. Findings indicate that traditional ways of teaching Supply Chain Management are not always effective and students expect a more student-centred pedagogy to improve the depth of their learning.
\end{abstract}

Paper type: Research paper

Keywords: supply chain management; higher education institutions; passive learning; active learning; criticism; problems; challenges; innovative teaching methods 


\section{Introduction}

In the UK, the manufacturing sector employs 2.9 million people, whereas transport and storage sector employs around 1.6 million people (Office for National Statistics, 2017). The sizeable workforce in the field of supply chain management calls for a greater understanding of the student expectations towards the Supply Chain Management (SCM) programmes.

The skills requirements for a SCM practitioner is quite complex and requires a wide range of skills, including: commercial skills, analytical abilities, problem-solving skills, technical knowledge of transport or warehouse operations, good understanding of IT applications (e.g. modelling tools, customer relationship management, esourcing etc.) as well as communication skills and motivational skills (Chartered Institute of Logistics and Transport, 2017; Bak and Boulocher-Passet, 2013; Jordan and Bak, 2016). However, studies have shown that there is a gap between what employers need and what business schools deliver (Bennis and O'Toole, 2005; Jordan and Bak, 2016; Lutz and Birou, 2013).

The Leitch Report in 2006 highlighted the need for better integration of employment and skills to increase sustainable employability and career progression. Bennis and O'Toole (2005) pointed out that business schools tend to emphasises the knowledge creation through research and do not relate enough it with the industry. The relevance gap between research and practice has received growing interest in recent years (Birkinshaw et al., 2016), urging the need to close the gap between research and practice. With a specific emphasis on SCM, this paper aims to analyse the current approaches in teaching SCM at the university level and based on that, proposes alternative and innovative approaches to teach SCM.

\section{Challenges faced by HEIs}

Equipping the workforce with necessary skills has always been on the agenda of higher education institutions (HEIs). What has changed is the way of achieving those objectives in the digital age. The challenge is that educators not only need to deliver content knowledge, but also promote employability skills that are in line with the expectations of employers and job-seekers. Drawing upon substantial national survey data as well as extensive qualitative and observational data from 270 colleges in the US, Levine and Dean (2012) found that students do not have the firm grip on adulthood and they lack the ability and attitudes needed for contemporary organisations. Levine and Dean (2012) describe today's college students as "utilitarian in their goals for college, weak in academic skills, beneficiaries of inflated grades" (Preface of their book Generation on a Tightrope: A Portrait of Today's College Student). Such observation can be found in other countries as well. In the UK, for example, Bachan (2017) confirmed the public speculation of grade inflation in UK higher education. On the other hand, in a study of consumerism in UK HEIs, Bunce et al. (2017) noted that students who do not identify themselves as learners have a high probability to develop a consumer-alike orientation, especially if they are self-funded

International Journal of Management and Applied Research, 2017, Vol. 4, No. 4 
students. The changing perception of students and the growing expectation towards employability skills pose challenge to HEIs in preparing individuals for employment.

In catering the need for equipping the growing populations with necessary skills, HEIs have moved from elite education to mass education. Mass higher education is expected to reinforce the role that policymakers expect HEI to play: as a change agent that facilitate economic development (Teixeira et al., 2013). The growth of private HEIs creates public private competition in higher education (Belfield and Levin, 2005), and at the same time public HEIs undergone a series of changes in financial management, namely reduced state-fund for higher education (Ford, 2017), increased tuition fees (Bunce et al., 2017), and budget-saving measures such as replacement of full-time faculty with part-time lecturers (Ford, 2017). This institutional drift indirectly leads to the emerging "student as consumer model" (Bunce et al., 2017). Empirical research (Bunce et al., 2017; Levine and Dean, 2012) noted the growing popularity of consumer orientation to higher education, where students often see themselves as "paying customers" rather than "learners". To a great extent, such perception gives rise to the notion that HEIs are service providers. HEIs have strengthened this notion by putting greater emphasis on student satisfaction and job prospect, rather than personal meaning and/or "research for the cultural benefits of society" (Ford, 2017: 560).

Many of these HEIs are still in the transition of change, and the rise of technological innovation accelerates that change. The introduction of Massive Open Online Course (MOOC), for instance, allows learners from various countries to equip themselves with necessary know-how at almost no cost. While MOOC is not without its challenges, it constitutes a subject of intense interest in the higher education sector and "engender[s] a much-needed push towards experimenting with different educational model" (Literat, 2015: 1173).

\section{Challenges in teaching SCM}

The growing complexity of SCM in the global environment (Trautrims et al., 2016) as well as the socio-economic factors such as consumerism in higher education (Bunce et al., 2017; Levine and Dean, 2012) and recent emphasis on industry relevance (Jordan and Bak, 2016) or practical relevance (Bennis and O'Toole, 2005). The challenges faced by the lecturers are as follows:

1. Complexity of SCM and changing skills requirements (Bak and Boulocher-Passet, 2013; Jordan and Bak, 2016; Trautrims et al., 2016)

2. Narrow the existing gap between industry and academia (Bennis and O'Toole, 2005; Bak and Boulocher-Passet, 2013; Fawcett and Rutner, 2014; Lutz and Birou, 2013)

3. SCM pedagogy has not changed much in decades (Lutz and Birou, 2013; Trautrims et al., 2016)

4. The use of technology in SCM and SCM education (Trautrims et al., 2016)

The first challenge is related to the growing complexity of SCM in the global environment (Jordan and Bak, 2016; Trautrims et al., 2016). Traditionally, the labour

International Journal of Management and Applied Research, 2017, Vol. 4, No. 4 
market is more focused on technical and functional competencies. In the past few decades, however, employers increasingly expect graduates to master employability skills such as communication, problem-solving, teamwork, and self-management (Chartered Institute of Logistics and Transport, 2017; Bak and Boulocher-Passet, 2013; Jordan and Bak, 2016; Wong et al., 2014). As a result, university students are not only educated for content knowledge but also trained for "marketable skills that will translate into jobs and income" (Ford, 2017: 560). Moreover, some employers expect a SCM professional not only need to understand their own discipline but also possess cross-functional skills to collaborate their own functions (Fawcett and Rutner, 2014; Trautrims et al., 2016). In a study of supply chain graduate skills, Jordan and Bak (2016) found that graduates are expected to have graduate skills which include time management, collaborative learning, teamwork and problem solving, along side with supply chain skills such as understanding and application of regulations. This trend in hiring needs to be considered in designing and implementing SCM programmes and courses. The changing skills requirements naturally lead to the next challenge: to ascertain the curriculum relevant to the industry.

The second challenge is about bridging the existing gap between academia and industry. There is a tendency to include industry perspective in developing SCM curriculum. According to Lutz and Birou, (2013: 456): "There was no inclusion of an industry perspective in determining what should be taught in these classes, just a list of what academics think should be taught. This leaves a gap that may cause students to be unprepared as they leave the classroom". In recent years, management education has become "less and less relevant to practitioners" (Bennis and O'Toole, 2005: 98). In a study 118 syllabi of logistics courses in six different countries, Lutz and Birou, (2013) found that majority of classes adopt a traditional research-oriented approach to logistics education. SCM practitioners do not perceive a clear connection between curriculum quality and academic research (Fawcett and Rutner, 2014). As a result, many organisations found that the graduates from business school somehow lack the skills they need (Bennis and O'Toole, 2005). The current mismatch between industry and academia perspectives regarding practical relevance reflects a need for revising and advancing the curriculum.

The third challenge is associated with teaching methods. Stand-and-deliver lecture remains as a dominant mode of content delivery in business courses (Grasas and Ramalhinho, 2016; Trautrims et al., 2016; Van Hoek, 2001). Given the fast-changing nature of SCM and rapid developments in technology, such traditional way of delivering content knowledge requires a more interactive setting (Trautrims et al., 2016) and student-centred (Grasas and Ramalhinho, 2016). The traditional lecture approach is often perceived as boring (Burke and James, 2008), which leads to next challenge: the need to revise teaching methods and module content.

In the past few decades, business schools have supplemented the lectures with a range of classroom activities such as simulations and games (Grasas and Ramalhinho, 2016), case studies (Bennis and O'Toole, 2005), group projects (Trautrims et al., 2016), and competitions (Grasas and Ramalhinho, 2016). In some business schools, students are given additional opportunities for learning provided by a range of activities conducted outside the classroom. These learning activities take place in the

International Journal of Management and Applied Research, 2017, Vol. 4, No. 4 
form of consultancy project (Bak and Boulocher-Passet, 2013), community work (Goffnett et al., 2013), work placements (Jordan and Bak, 2016), and site visits (Goffnett et al., 2013). Many of these activities fall under the umbrella term of active learning (Grasas and Ramalhinho, 2016); a form of learning which actively engages students in the learning process. Unlike traditional lecture-based approach, active learning is more student-centred, in which students participate actively in the course (Trautrims et al., 2016) and also solve problems -- either in real-life setting (Bak and Boulocher-Passet, 2013) or virtual setting (Grasas and Ramalhinho, 2016). Students benefit from such student-centred methodology because it provides the opportunity to build SCM skills (Goffnett et al., 2013) and facilitate deep learning (Trautrims et al., 2016). Given the growth of educational technology and the changing expectation towards higher education, a more student-centred approach to SCM education is needed.

Technological advances in the past few decades not only transform the supply chain management at global context, but also introduce changes to how and what students learn in the universities. Nowadays, students are required to understand the dynamics of online retailing and its operational activities (Lutz and Birou, 2013). Additionally, they are given options to learn collaboratively in an online setting (Trautrims et al., 2016). These are the changes that reflect the need to embrace innovative teaching methods used in SCM programmes as well as it content delivery.

\section{Challenges for students}

The current literature on SCM education suggests that students also face challenges in learning such as lack of interest (Lancioni et al., 2001), translating theoretical concepts into real-life (Bak and Boulocher-Passet, 2013), and fear of uncertainty after graduation (Perrone and Vickers, 2003).

- According to Lancioni et al. (2001), one of the barriers that have hindered the development of logistics programmes is the lack of interest from the students. The lack of a profession-wide certification (Fawcett and Rutner, 2014) might explain the general lack of interest. Wong et al. (2014) found that graduates are competing with high-school qualifications and diploma-holders for entry-level jobs in the SCM industry. However, Wong et al. (2014) also found that organisations prioritise degree qualification for both mid-level and executive level jobs in SCM. This suggests that degree qualification is not a priority for entry-level jobs in SCM, but it is an essential criterion for higher-levels jobs. In all levels of jobs, employers look for someone who has relevant work experiences, which represents a challenge for the students.

- Work experience or workplace exposure is essential for development of SCM skills as it helps to practice new skills and subject knowledge (Jordan and Bak, 2016). Students with limited exposure often have difficulty in making sense of complex subjects such as the sophistication of logistics problems and operations research techniques (Grasas and Ramalhinho, 2016). In a study of job advertisements for 12 weeks between 2011 and 2012, Wong et al. (2014) found that even entry-level jobs in the SCM industry require work experience. Perrone

International Journal of Management and Applied Research, 2017, Vol. 4, No. 4 
and Vickers (2003) argued that such employer requirement is overly high and they claim that "entry-level work, especially if unpaid, is notorious for requiring mindless obedience and patience with the photocopier, rather than allowing educated, intelligent students to excel in communication and language skills, and other business related competencies" (p. 75). Such work experience paradox (Perrone and Vickers, 2003) naturally leads to the next challenge: students are uncertain about their future career path.

- For some business graduates, life after graduation is uncertain, especially in terms of their future career path (Perrone and Vickers, 2003). Given the competitive job market, graduates increasingly searching for jobs outside that are unrelated to their degrees. Career indecision among graduates is not uncommon, particularly for those who have difficulty to get a job that matches their expertises and interests (Okay-Somerville and Scholarios, 2014). Although business degrees offer a broad spectrum and job prospects, some business students may be overwhelmed with the complexity of the world of work and unprepared for their future career (Perrone and Vickers, 2003).

\section{Methodology}

This study used two methods to gather data from the participants of supply chain management Postgraduate and Undergraduate modules: questionnaire and in depth interviews. In-depth interviews were used to get student's opinions and experiences related to the challenges of learning SCM, followed by questionnaire to validate the findings of interviews. While the in-depth interviews were limited to a handful of respondents having strongly articulated views, using convenience sampling method (Bryman and Bell, 2015), for questionnaire 98 past participants of supply chain management modules were invited. The response rate was $42 \%$, which is a relatively good response rate considering the fact of retrospective surveying, i.e. up to one year after completing the SCM module. In total 15 statements using Likert scale were designed where participants could answer each statement with the following choices: strongly agree, agree, neither agree or disagree, disagree and strongly disagree. Each student was approached by email asking to complete the questionnaire. Each questionnaire had a brief explanation on how to answer it and outlined assurance that strictly confidentiality would be guaranteed. Additionally, a total of 10 lecturers were interviewed with pre-structured questions to contrast the student's and staff views.

\section{Main Findings}

Perceived career path

Findings show that students are not fully aware of the job opportunities available within SCM, as majority of the respondents $(90.2 \%)$ found difficulty to identify SCM jobs available as a career path. In particular, majority of the respondents could not see their career in SCM. Nearly three quarters of the respondents $(70.8 \%)$ were unclear with their career after graduation $(70.8 \%$ of respondents disagree with the statement "when I was learning SCM, I already knew which job I would like to have after completion of my study"). This finding is consistent with the existing literature in which some business students are uncertain for their career path (Okay-Somerville

International Journal of Management and Applied Research, 2017, Vol. 4, No. 4 
and Scholarios, 2014; Perrone and Vickers, 2003). To a certain extent, job counselling and giving career advice to students could help students to be more confident in their future career. Students are more likely to success in their logistics programmes if their HEIs offer effective career advice in logistics (Lancioni et al., 2001).

Some interviewed lecturers do not explain the relevance of SCM to the daily life and illustrate possible career choices for students. Mainly, they consider this is the task for Career Service, a job counselling service provided by the HEIs in the UK. One of the interviewed lecturers asked students (during the first session of the module) to describe what it means SCM, and yet many students struggle to answer the question as the subject is too abstract for them. An induction to the career in SCM during the beginning and/or the end of the module could help students to have a clearer picture of their future career path.

\section{Work experience}

Nearly four fifth (77.5\%) of the respondents consider work experience helps them to understand how SCM work in practice. This finding is aligned with the common belief that work exposure can help students to comprehend the theoretical concepts (e.g. Grasas and Ramalhinho, 2016; Jordan and Bak, 2016).

Vast majority of the respondents (95\%) believe that industry experience of the lecturer helps them to better understand the concepts of SCM. Students reported they valued the real-life case examples provided during class by their lecturer because those examples help them to grasp the conceptual models in SCM.

Nearly all interviewed lecturers agree with the view that work experience (even unrelated one) can hep to students to understand better. They commented that inexperienced students often have difficulty to grasp some complex theoretical models, and require more time in teaching. This is consistent with the scholarly view that the exposure to real-life problems (Bak and Boulocher-Passet, 2013), global virtual team (Trautrims et al., 2016), or even decision support system (Grasas and Ramalhinho, 2016) helps students to better prepare for their future career.

\section{Teaching methods}

Less than half of the respondents consider lecture is a useful means of learning (about $44 \%$ of the respondents disagree with the view that "lectures help me to learn SCM better" and $27 \%$ of the respondents neither agree nor disagree). More than half of the students do not consider guest lecture as beneficial to their learning (68\% of the respondents disagree with the statement "guest lecture helps me to understand the link between theory and practice"). This finding is contrary to Van Hoek (2001) who highlighted the learning effectiveness of guest lecture to logistics students. Some respondents consider guest lecture as "waste of time" and the content of guest lecture was "remotely relevant" to their learning. The negative review regarding lecture and guest lecture could be attributed to the passive nature of lecture-based approach where students are passive in the learning process. Interestingly, students are more interested in multimedia illustrations, as $68 \%$ of the respondents strongly agree with the view that multimedia illustrations help them to learn SCM better. They consider the

International Journal of Management and Applied Research, 2017, Vol. 4, No. 4 
multimedia illustrations as an enjoyable learning experience and express their preference toward multimedia over lecturing.

Additionally, students are also interested in a more engaging form of learning, namely simulation, case studies, and group presentation. These learning activities consist of varying degree collaborative problem-based learning while students were required to work in group, either to discuss logistics problems or solve a problem. While some students express their dislike towards groupwork and described it as "annoying", majority of the respondents agree with the view that working in group improves their learning.

Some of the interviewed lecturers maintain the learning effectiveness of the conventional lecture-based approach. While some of the lecturers actively find ways to engage students in the learning process, most of them are overwhelmed by the spiralling duties and responsibilities. They expressed their concern that their duties are not just limited to curriculum delivery, classroom management, assessment, research, and continuous professional development; they are also required to be innovative in their teaching without having the needed infrastructure and ample time for preparation.

\section{Conclusions}

This paper explores the challenges faced by the students and lecturers in teaching and learning SCM. Due to the exploratory nature of the study, the limitations of this study include: small sample, insufficient time and scope of the content to address many issues one would like to investigate (Bak and Boulocher-Passet, 2013). Nonetheless, the findings of this research shed some light on the SCM education. The literature review in this study identifies four challenges faced by the SCM lecturers and three main challenges faced by the students. These challenges may vary within time and across the countries. The results of this study showed that learners' needs are constantly changing and students have mixed feelings towards teaching methods used in the SCM programmes. Despite guest lecture and groupwork are widely recognised as effective teaching methods, participated SCM students consider it as "waste of time" and "annoying". Further research is needed to investigate the underlying causes of such negative views.

Besides challenges faced by both SCM lecturers and students, this paper also reviewed the challenges faced by HEIs in general. These challenges revolve around political changes, socio-economic factors as well as technological innovations. There is a common perception that higher education should be widely accessible, affordable, and HEIs should be accountable to the society they service (Ford, 2017). The transformation from elite to mass higher education, financial constraints, growing expectations of all stakeholders (policymaker, employer, student, media), emerging educational models all constitute challenges to HEI. Further research, which could be of academic interest to scholars, could include:

- A longitudinal research which examines the attitudes and behaviours of learners towards SCM programmes over time.

International Journal of Management and Applied Research, 2017, Vol. 4, No. 4 
- A comparative study which evaluates the learning effectiveness of SCM programmes in different country.

- An experimental research which assesses the learning effectiveness of teaching methods using test-scores of control group and experimental group.

The findings of this study also encourage further discussion into innovative teaching methods that are more student-centred and how these can be embedded in SCM syllabus. This requires a review and reflection upon current pedagogies used in the current SCM courses. Further research could also consider the assessments used in SCM courses, linking them with SCM skills that are required in the job market.

\section{References}

1. Bachan, R. (2017), "Grade inflation in UK higher education", Studies In Higher Education, Vol. 42, No. 8, pp. 1580-1600. https://doi.org/10.1080/03075079.2015.1019450

2. Bak, O. and Boulocher-Passet, V. (2013), "Connecting industry and supply chain management education: exploring challenges faced in a SCM consultancy module", Supply Chain Management: An International Journal, Vol. 18, No. 4, pp. 468-479, https://doi.org/10.1108/SCM-11-2012-0357

3. Belfield, C. and Levin, H. M. (2005), Privatizing Educational ChoiceConsequences for Parents, Schools, and Public Policy, London: Paradigm Publishers.

4. Bennis, W.G. and O'Toole, J. (2005), "How business schools lost their way", Harvard Business Review, Vol. 83 No. 5, pp. 96-104.

5. Birkinshaw, J.; Lecuona, R. and Barwise, P. (2016), "The Relevance Gap in Business School Research: Which Academic Papers Are Cited in Managerial Bridge Journals?", Academy Of Management Learning \& Education, Vol. 15, No. 4, pp. 686-702. https://doi.org/10.5465/amle.2015.0282

6. Bryman, A. and Bell, E. (2015), Business Research Methods, $3^{\text {rd }}$ ed. New York: Oxford University Press.

7. Bunce, L., Baird, A., and Jones, S. E. (2017), "The student-as-consumer approach in higher education and its effects on academic performance", Studies In Higher Education, Vol. 42, No. 11, pp. 1958-1978. https://doi.org/10.1080/03075079.2015.1127908

8. Burke, L. A. and James, K. E. (2008), "PowerPoint-Based Lectures in Business Education: An Empirical Investigation of Student-Perceived Novelty and Effectiveness", Business and Professional Communication Quarterly, Vol. 71, No. 3, pp. $277-296$.

International Journal of Management and Applied Research, 2017, Vol. 4, No. 4 
9. Chartered Institute of Logistics and Transport (2017), A career in supply chain management, [Online] available from: https://ciltuk.org.uk/Careers/CareersInformation/Career-Profiles/Supply-Chain-Management [Accessed on 3 Dec 2017].

10. Fawcett, S. E. and Rutner, S. M. (2014), "A longitudinal view of supply chain education: Assessing the challenge of retaining relevance in today's dynamic marketplace", The International Journal of Logistics Management, Vol. 25 Issue: 1, pp.180-201, https://doi.org/10.1108/IJLM-07-2012-0061

11. Ford, M. (2017), "The Functions of Higher Education", American Journal of Economics And Sociology, Vol. 76, No. 3, pp. 559-578.

12. Grasas, A. and Ramalhinho, H. (2016) "Teaching distribution planning: a problem-based learning approach", The International Journal of Logistics Management, Vol. 27, No. 2, pp. 77-394, https://doi.org/10.1108/IJLM-05-2014$\underline{0075}$

13. Goffnett, S. P.; Helferich, O. K. and Buschlen, E. (2013), "Integrating servicelearning and humanitarian logistics education", Journal of Humanitarian Logistics and Supply Chain Management, Vol. 3, No. 2, pp.161186, https://doi.org/10.1108/JHLSCM-09-2012-0022

14. Jordan, C. and Bak, O. (2016), "The growing scale and scope of the supply chain: a reflection on supply chain graduate skills", Supply Chain Management: An International Journal, Vol. 21, No. 5, pp. 610-626, https://doi.org/10.1108/SCM$\underline{\text { 02-2016-0059 }}$

15. Lancioni, R.; Forman, H. and Smith, M. F. (2001), "Logistics and supply chain education: Roadblocks and challenges", International Journal of Physical Distribution \& Logistics Management, Vol. 31, No. 10, pp.733-745. https://doi.org/10.1108/EUM0000000006287

16. Leitch, S. (2006), Leitch Review of Skills. Prosperity for all in the global economy - world class skills: Final Report. Norwich: HM Treasury. [Online] available from:

https://www.gov.uk/government/uploads/system/uploads/attachment_data/file/243 599/0118404865.pdf [Accessed on 3 Dec 2017].

17. Levine, A. and Dean, D. R. (2012), Generation on a tightrope: A portrait of today's college student, San Francisco: Jossey-Bass.

18. Literat, I. (2015), "Implications of massive open online courses for higher education: mitigating or reifying educational inequities?", Higher Education Research \& Development, Vol. 34, No. 6, pp. 1164-1177. https://doi.org/10.1080/07294360.2015.1024624 
19. Lutz, H. and Birou, L. (2013) "Logistics education: a look at the current state of the art and science", Supply Chain Management: An International Journal, Vol. 18, No. 4, pp.455-467, https://doi.org/10.1108/SCM-08-2012-0269

20. Perrone, L. and Vickers, M. H. (2003), "Life after graduation as a "very uncomfortable world': an Australian case study", Education + Training, Vol. 45, No. 2, pp. 69-78, https://doi.org/10.1108/00400910310464044

21. Office for National Statistics (2017), Employment by Industry, [Online] available from:

https://www.ons.gov.uk/generator?uri=/employmentandlabourmarket/peopleinwor k/employmentandemployeetypes/bulletins/uklabourmarket/november2017/1eaa83 $\underline{23 \& \text { format }=x l s}$ [Accessed on 3 Dec 2017].

22. Okay-Somerville, B. and Scholarios, D. (2014), "Coping with career boundaries and boundary-crossing in the graduate labour market", Career Development International, Vol. 19, No. 6, pp.668-682, https://doi.org/10.1108/CDI-12-2013$\underline{0144}$

23. Teixeira, P.; Rocha, V.; Biscaia, R. and Cardoso, M. F. (2013), "Competition and diversification in public and private higher education", Applied Economics, Vol. 45, No. 35, pp. 4949-4958. https://doi.org/10.1080/00036846.2013.808310

24. Trautrims, A.; Defee, C. and Farris, T. (2016), "Preparing business students for workplace reality - using global virtual teams in logistics and SCM education", The International Journal of Logistics Management, Vol. 27, No. 3, pp. 886-907, https://doi.org/10.1108/IJLM-01-2015-0003

25. Wong, C. Y.; Grant, D.; Allan, B. and Jasiuvian, I. (2014) "Logistics and supply chain education and jobs: a study of UK markets", The International Journal of Logistics Management, Vol. 25, No. 3, pp. 537-552. https://doi.org/10.1108/IJLM-01-2013-0003

26. Van Hoek, R.I. (2001), "Logistics education: achieving market and research driven skill development", International Journal of Physical Distribution \& Logistics Management, Vol. 31 No. 7, pp. 505-519. https://doi.org/10.1108/EUM0000000005906 